\title{
Selbstüberwachung und online Verifizierung von Sensordaten im Kraftfahrzeug
}

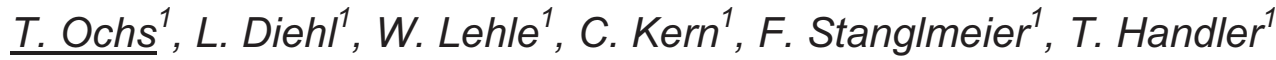 \\ ${ }^{1}$ Robert Bosch GmbH, Stuttgart/Deutschland, \\ Corresponding author's e-mail address
}

\begin{abstract}
:
Getrieben durch die sich immer weiter verschärfende Abgasgesetzgebung werden das Motorsystem und die einzelnen Komponenten im Fahrbetrieb kontinuierlich überwacht. Beginnend in Kalifornien (1988 On Board Diagnose (OBDI) wurden die Überwachungsanforderungen der emissionsrelevanten Komponenten standardisiert. Hierbei muss sichergestellt werden, dass alle Komponenten, deren Ausfall zu einer Verschlechterung der Abgasemissionen führt, im Motorsteuergerät überwacht werden. Dazu werden im Abgasnachbehandlungssystem unterschiedliche Sensoren eingesetzt (z.B. NOx-, Partikel- und Lambda-Sonde). Diese Sensoren müssen als Bestandteile des Emissions- und Überwachungskonzepts selbst überwacht werden.

Im Vortrag wird der aktuelle Stand der Abgas- und OBD-Gesetzgebung in USA und Europa vorgestellt. Der Einsatz von Sensoren zur Überwachung unterschiedlicher Abgasnachbehandlungskomponenten wird ebenso wie die daraus abgeleiteten Anforderungen an die Selbstüberwachung und online Verifizierung der Sensordaten an unterschiedlichen Beispielen diskutiert und Lösungsansätze hierfür vorgestellt.
\end{abstract}

\section{Abstract:}

The emission legislation world-wide becomes more and more stringent which lead to a continuous monitoring of the engine system and the different components in driving mode. Starting in California (1988 On Board Diagnostics (OBDI)) the regulations regarding the monitoring of the emission relevant components were standardized. All exhaust-gas-related systems and components have to be monitored in driving mode. All sensors (e.g. NOx-, Particulate Matter, Lambda sensor) and actuators which having either an impact on emissions or are being used to monitor other components or systems have to be monitored according the OBD legislation, too.

The status of the emission legislation and the OBD regulation for NOx and PM in USA and Europe will be presented. Diesel exhaust gas systems and examples of the required sensors for Euro 6 and US market will be explained. The requirements for the sensors and an overview of present Bosch monitoring functions for oxygen sensors will be discussed.

Key words: On Board Diagnostics, oxygen sensor, exhaust gas legislation, sensor monitoring

\section{OBD (On-Board Diagnostics)}

The emission-control legislation and the regulations for on-board diagnostics world-wide become more and more stringent (see fig. 1).

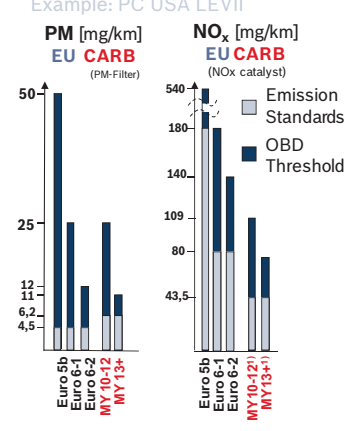

Fig. 1: Emission standards and $O B D$ threshold limits for PM and NOx in EU and USA 
The lawmakers have acknowledged on-board diagnostics (OBD) as an aid to continuous monitoring the emission of the vehicle over life time. In EU and especially in US the OBD requirements are enforced in the last years (see fig 1).

The engine system and components must be continuously monitored by the OBD system in driving mode so that compliance with the emission limits required by law can be achieved in everyday use. Therefore regulations were adopted to monitor exhaust-gas-related systems and components. Any errors or faults detected are stored in the control-unit fault memory and the malfunction indicator lamp (MIL) has to be switch on to informs the driver that a component has malfunctioned.

For all sensors and actuators which having either an impact on emissions or are being used to monitor other components or systems (and consequently may if necessary disable other diagnoses) have to be monitored according the OBD legislation for "comprehensive components".

The sensors have to be monitoring for the following faults:

- Electrical faults, i.e. short-circuits and line breaks ("Signal Range Check")

- Range faults ("Out of Range Check"), i.e. undercutting or exceeding voltage limits set by the sensors' physical measurement range

- Plausibility faults (“Rationality Check”); these are faults that are inherent in the components themselves (e.g. drift), or which may be caused by shunts, for instance. Monitoring is carried out by a plausibility check on the sensor signals, either by using a model or directly by other sensors

\section{Exhaust Gas Treatment Systems}

Depending on market, vehicle class and system cost aspects different exhaust gas systems can cover the respective legislation requirements. With introduction of Euro 4 and 5 , diesel oxidation catalyst and diesel particulate trap had been already introduced in to market to reach the emission limits regarding $\mathrm{HC}, \mathrm{CO}$ and PM. Due to reduced NOx emission limits with introduction of EU6, additional NOx reduction measures are required. Two technologies to reduce NOx emissions in exhaust gas after treatment are well known and some car manufactures have already introduced these technologies in to the market, NOx Storage Catalyst (NSC) and Selective Catalytic Reduction (SCR).

Depending on the required NOx efficiency which mainly depends on NOx engine out emissions, both technology can be used.

Empirically, NSC would be the favorite technology for smaller vehicle while SCR technology will be mandatory for larger passenger cars, SUVs and Light duty vehicles. The used exhaust gas system technology determines the types and number of exhaust gas sensors to fulfill emission targets and OBD requirements depending on legislation. For each technology one example for exhaust gas configuration and use cases of exhaust gas sensors are shown in figure 2.
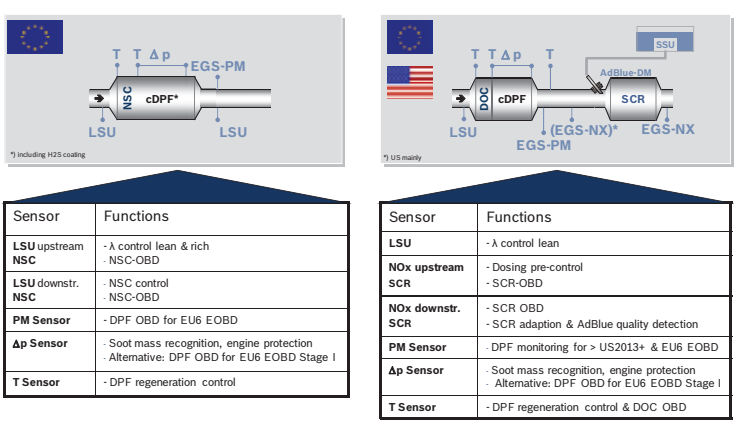

Fig. 2: Diesel exhaust gas systems and required sensors for Euro 6 and US market

Temperature and differential pressure sensors are mainly used for DPF control.

Expediently, NSC is placed close to the engine. First oxygen sensor supports lambda control functions to reduce the dispersion of engine out emissions during lean operation and is used for lambda control to regenerate the NSC with rich gas, i.e. lambda $<1$.

The second oxygen sensor downstream the coated diesel particulate filter (cDPF) is required to control and monitor the NSC.

The SCR catalyst system consists of a SCR catalyst, an AdBlue dosing system and a NOx sensor downstream the SCR. NOx sensor downstream SCR is required for SCR adaptation functions and to monitor the SCR system. Depending on legislation and NOx engine out emissions a second NOx sensor upstream SCR catalyst is reasonable. 
Due to the emission impact and the use for monitoring of the SCR system, exhaust gas sensors have to be monitored themselves according to the requirements described in chapter OBD.

\section{Parts of the Lambda sensor}

The ceramic sensor element for the oxygen sensor is pressed into the sensor housing with a packing, so that exhaust gases are prevented from diffusing into the interior of the housing see figure 3 [1].

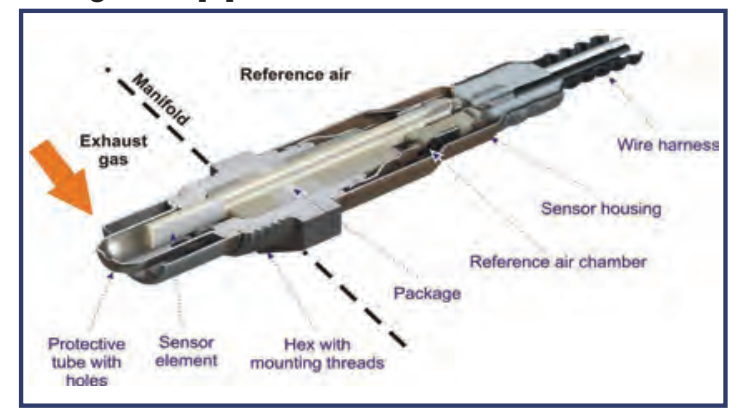

Fig. 3.: Schematic view of a broadband oxygen sensor

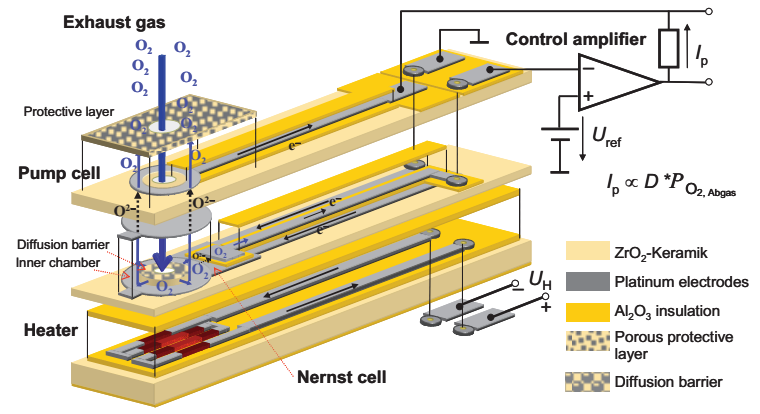

Fig. 4: Schematic view of a broadband oxygen sensor element

In the broadband oxygen sensor element, exhaust gas diffuses through the hole (blue arrow) and the diffusion barrier into an inner chamber between the electrodes. The pump cell pumps oxygen out of the inner chamber. The Nernst cell serves to measure the oxygen content of the inner chamber. The control amplifier adjusts the pump current such that $\lambda=$ 1 in the inner chamber. The pump current is used as a measurement signal. The insulated platinum heater in the aluminum oxide below serves to heat the sensor element. A small additional reference pump current maintains the air reference for the Nernst cell.

\section{Monitor requirements for Oxygen Sensors}

For the oxygen sensor, for example, all wires, the heater performance (OBDI) and the signal quality (OBDII) have to be monitored in-use.

Figure 5 shows an overview of present Bosch monitoring functions for oxygen sensors to fulfill US and Euro 6 OBD requirements.

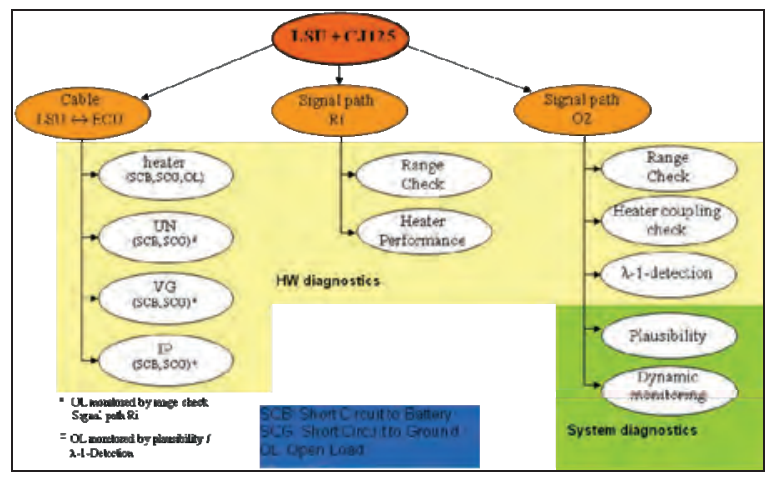

Figure 5: Overview of Bosch ECU SW functions to monitor Bosch Oxygen Sensors

\section{References}

[1] T.Baunach, K. Schänzlin und L.Diehl, Sauberes Abgas durch Keramiksensoren, Physik Journal 5 33-38 (2006) 